\title{
Iron limitation of the postbloom phytoplankton communities in the Iceland Basin
}

\author{
Maria C. Nielsdóttir, ${ }^{1}$ Christopher Mark Moore, ${ }^{1}$ Richard Sanders, ${ }^{1}$ Daria J. Hinz, ${ }^{1}$ \\ and Eric P. Achterberg ${ }^{1}$
}

Received 22 October 2008; revised 6 April 2009; accepted 23 April 2009; published 1 July 2009.

[1] Measurements performed on a cruise within the central Iceland Basin in the highlatitude $\left(>55^{\circ} \mathrm{N}\right)$ North Atlantic Ocean during late July to early September 2007 indicated that the concentration of dissolved iron $(\mathrm{dFe})$ in surface waters was very low, with an average of $0.093(<0.010-0.218, \mathrm{n}=43) \mathrm{nM}$, while nitrate concentrations ranged from 2 to $5 \mu \mathrm{M}$ and in situ chlorophyll concentrations ranged from 0.2 to $0.4 \mathrm{mg} \mathrm{m}^{-3}$. In vitro iron addition experiments demonstrated increased photosynthetic efficiencies $\left(\mathrm{F}_{\mathrm{v}} / \mathrm{F}_{\mathrm{m}}\right)$ and enhanced chlorophyll accumulation in treatments amended with iron when compared to controls. Enhanced net growth rates for a number of phytoplankton taxa including the coccolithophore Emiliania huxleyi were also observed following iron addition. These results provide strong evidence that iron limitation within the postspring bloom phytoplankton community contributes to the observed residual macronutrient pool during summer. Low atmospheric iron supply and suboptimal Fe: $\mathrm{N}$ ratios in winter overturned deep water are suggested to result in the formation of this seasonal high-nutrient, lowchlorophyll (HNLC) condition, representing an inefficiency of the biological (soft tissue) carbon pump in the region.

Citation: Nielsdóttir, M. C., C. M. Moore, R. Sanders, D. J. Hinz, and E. P. Achterberg (2009), Iron limitation of the postbloom phytoplankton communities in the Iceland Basin, Global Biogeochem. Cycles, 23, GB3001, doi:10.1029/2008GB003410.

\section{Introduction}

[2] Iron availability has now been demonstrated to perform a fundamental role in controlling photosynthesis and phytoplankton biomass accumulation in all the classical high-nutrient, low-chlorophyll (HNLC) systems [Boyd et al., 2007; de Baar et al., 2005]. In contrast, it is generally assumed that the high-latitude $\left(>\sim 50^{\circ} \mathrm{N}\right)$ North Atlantic Ocean fundamentally differs from the other high-latitude regions of the global oceans (i.e., the HNLC Southern Ocean and subpolar North Pacific), as iron is considered not to be a limiting micronutrient [Martin et al., 1993].

[3] A pronounced spring bloom is observed in the highlatitude North Atlantic. Deep winter overturning $(>600 \mathrm{~m})$ injects nitrate into surface waters, resulting in prebloom concentrations of $>10 \mu \mathrm{M} \mathrm{NO}_{3}^{-}$[Ducklow and Harris, 1993; Sanders et al., 2005]. Increased incident surface irradiance in the spring subsequently results in a shoaling of the mixed layer to less than the critical depth [Siegel et al., 2002; Sverdrup, 1953]. This transient period during which the average light intensity of the mixed layer is increasing and nutrient concentrations are high provides a window of opportunity for the onset of a large phytoplank-

\footnotetext{
${ }^{1}$ Ocean Biogeochemistry and Ecosystems Research Group, National Oceanography Centre, School of Ocean and Earth Science, University of Southampton, Southampton, UK.

Copyright 2009 by the American Geophysical Union. 0886-6236/09/2008GB003410
}

ton bloom. Chlorophyll concentrations during the spring bloom peak at $>2 \mathrm{mg} \mathrm{m}^{-3}$ in parts of the high-latitude North Atlantic and subsequently significant drawdown of surface macronutrients occurs along with high rates of export [Honjo and Manganini, 1993].

[4] The sequence of events surrounding the spring bloom is well established [Sverdrup, 1953]. However, despite the transient spring period of high biomass and hence productivity and export, in many regions of the open North Atlantic, including the Iceland and Irminger Basins, residual nitrate $\left(>2 \mu \mathrm{M} \mathrm{NO}{ }_{3}^{-}\right)$and phosphate $\left(>0.15 \mu \mathrm{M} \mathrm{PO}_{4}^{3-}\right)$ concentrations have been observed during the postbloom summer period [Sanders et al., 2005]. Persistent highmacronutrient conditions throughout the postbloom period represent an inefficiency of the biological (soft tissue) carbon pump [Sarmiento and Toggweiler, 1984]. Moreover the existence of such residual nutrients in the high-latitude Atlantic is potentially of global significance to the partitioning of carbon between the atmosphere and ocean [Marinov et al., 2008a, 2008b].

[5] North Atlantic Deep Water (NADW) is formed in the subpolar gyre, in the Greenland Sea and in the Norwegian Sea of the high-latitude North Atlantic, and contributes approximately half of the global production of deep waters. Atmospheric $\mathrm{pCO}_{2}$ is particularly sensitive to inefficiencies in the biological pump in regions of deep water formation [Knox and McElroy, 1984; Sarmiento and Toggweiler, 1984; Sarmiento and Orr, 1991; Siegenthaler and Wenk, 1984]. Indeed, modeling studies have indicated that com- 
plete nutrient removal in the high-latitude North Atlantic would potentially be more significant in lowering atmospheric $\mathrm{pCO}_{2}$ than either the HNLC sub-Arctic or equatorial Pacific, and is second only to the Southern Ocean in terms of influence [Marinov et al., 2008a; Sarmiento and Orr, 1991].

[6] The mechanism(s) responsible for maintaining residual macronutrients in the high-latitude North Atlantic likely comprise some combination of the factors that have previously been identified in the more classical HNLC systems [Cullen, 1991]. The potential for high-grazing rates, particularly on small phytoplankton groups by rapidly growing heterotrophic protists [Banse, 1982], has frequently been identified as a factor capable of limiting the standing stock of major sections of the autotrophic community [Frost, 1991; Walsh, 1976]. Consequently grazer termination of the bloom has been hypothesized [Banse, 2002]. Additionally, the large diatoms, that potentially could escape highgrazing mortality because of good defenses [Hamm et al., 2003], may be silicate limited, preventing further drawdown of residual nitrate and phosphate [Dugdale and Wilkerson, 1998; Henson et al., 2006].

[7] Such arguments were the leading candidate mechanisms in the classical HNLC systems [Dugdale and Wilkerson, 1998; Frost, 1991; Walsh, 1976], until the unequivocal demonstration of iron limitation for at least some components of the phytoplankton community [Boyd et al., 2007; Martin and Fitzwater, 1988; Martin et al., 1994]. Subsequently it was recognized that these factors may all interact and contribute to the maintenance of residual macronutrients in HNLC systems [Cullen, 1991; Dugdale and Wilkerson, 1998; Morel et al., 1991; Price et al., 1994].

[8] Although iron availability has been assumed to exert little control on phytoplankton growth and biogeochemical cycling in the North East Atlantic [Martin et al., 1993], the high-latitude North Atlantic receives very low dust and hence atmospheric iron inputs, which are comparable with the HNLC North Pacific [Jickells et al., 2005]. Additionally, early work highlighted very low dissolved iron ( $\mathrm{dFe}$ ) concentrations in the region during late spring/early summer (June) and provided evidence for increased $\mathrm{CO}_{2}$ fixation and particulate organic carbon production following iron additions within bottle experiments [Martin et al., 1993]. More recent measurements have shown low $\mathrm{dFe}(0.02-$ $0.16 \mathrm{nM}$ ) south of Iceland [Measures et al., 2008] and experimental manipulations [Blain et al., 2004; Moore et al., 2006] and in situ physiological measurements [Moore et al., 2006] further to the south $\left(\sim 40^{\circ} \mathrm{N}\right)$ have indicated the potential for iron limitation in the North Atlantic Ocean.

[9] The aim of the current study was to establish if iron availability influences phytoplankton growth during postbloom conditions in the Iceland Basin and hence whether low iron supply plays a role in the persistence of any postbloom residual macronutrient pool. A number of complementary techniques were employed, including measurements of $\mathrm{dFe}$ concentrations and in vitro bioassay experiments. Interpretation of such bottle experiments is complicated by the potential for artifacts following removal of the natural population from the in situ environment [Cullen, 1991]. Consequently biophysical measurements of both in situ and experimental phytoplankton populations were performed as a potential means of overcoming these weaknesses [Geider and La Roche, 1994].

\section{Methods}

\subsection{General}

[10] Data were obtained during a two leg cruise from 25 July to 9 September 2007. During the first leg of the cruise, three bioassay experiments $(\mathrm{A}-\mathrm{C})$ and six stations $(800-$ $1000 \mathrm{~m}$ ) were sampled in the middle of the sub polar gyre in the Iceland Basin. On the second leg of the cruise, a further experiment (D) was carried out closer to the Iceland Shelf (Figure 1a), and stations were occupied between Iceland and the UK. Hydrographic data were collected using Seabird 9/ $11+$ CTD systems, incorporating a $2 \pi$ irradiance sensor. CTD data were used to calculate mixed layer depths (MLD), the diffuse attenuation coefficient $\left(\mathrm{k}_{\mathrm{d}}\right)$ and hence maximum, minimum and mean $\left(\mathrm{E}_{\mathrm{avg}}\right)$ irradiances within the mixed layer, hereafter quoted as a function of the surface value $\left(\mathrm{E}_{\mathrm{o}}\right)$.

\subsection{Sample Collection}

[11] Discrete water samples and vertical profiles of temperature and salinity were collected using two separate CTD rosette systems. A trace metal clean titanium CTD rosette with $10 \mathrm{~L}$ trace metal clean Teflon coated OTE bottles, fitted with silicone $\mathrm{O}$ rings and plastic coated springs, was used for the collection of samples analyzed for dissolved iron $(\mathrm{dFe})$, dissolved aluminum (dAl) and incubation experiments. Additionally, water for the incubation experiments and surface dFe determinations was also collected using a trace metal clean tow fish [Bowie et al., 2001] while the ship was steaming at 10 knots. The seawater was pumped into a dedicated clean chemistry container using a Polytetrafluoroethylene (PTFE) diaphragm pump (Almatec -15$)$. Discrete samples for other measurements such as macronutrients were frequently taken from either a stainless steel CTD rosette with standard Niskin bottles or from the titanium CTD rosette, depending on the order of the casts. Samples for the analysis of surface chlorophyll and macronutrients were also collected from the ship's sea underway seawater supply, which has an intake at a depth of $\sim 5 \mathrm{~m}$.

\subsection{Iron-Light Enrichment Experiments}

[12] Incubation experiments were performed using a similar method to that employed previously in the HNLC Southern Ocean [Moore et al., 2007]. Briefly, water for incubation experiments was collected using either the trace metal titanium CTD rosette system (experiments A and B) or the trace metal clean tow fish (experiments $\mathrm{C}$ and D) and transferred unscreened into acid washed $4.8 \mathrm{~L}$ polycarbonate bottles (Nalgene). Incubation bottles and three initial samples were filled randomly, then either left as controls or amended with acidified $\mathrm{FeCl}_{3}$ to a final concentration of $2 \mathrm{nM}$ above the ambient $\mathrm{dFe}$ concentration. All bottle tops were sealed with film (Parafilm) and bottles were double bagged with clear plastic bags to minimize contamination risks on deck. On deck incubations were performed over 56 days at two different irradiance levels, high light (HL) and low light (LL). The incubators for the HL and LL light treatments were shaded using a combination of neutral density and blue lagoon filters to levels corresponding to 

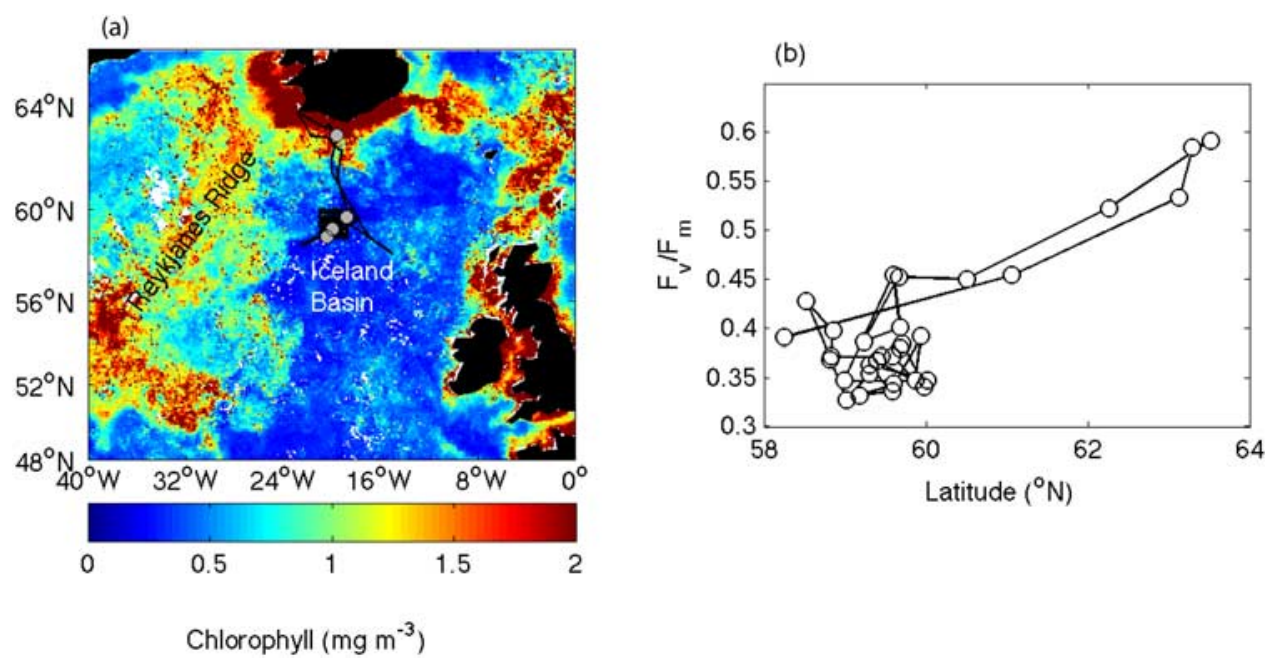

Figure 1. (a) Bioassay experiments superimposed on average SeaWiFS-derived chlorophyll image for August 2007. Black line indicates cruise track. (b) South-north increase in the maximum photosynthetic efficiency for photosystem II $\left(\mathrm{F}_{\mathrm{v}} / \mathrm{F}_{\mathrm{m}}\right)$ along cruise tracks indicated in Figure 1a as estimated by maximum daily ratios of variable to maximal fluorescence observed postdawn.

$35 \%$ and $4 \%$ of $\mathrm{E}_{0}$, respectively. The temperature in the incubators was controlled by running surface seawater. Typical experimental treatments consisted of high-light and low-light controls (HLC and LLC) and high-light and low-light iron (HLFe and LLFe) amended. For experiment A, only the HL light regime was used. For experiment $\mathrm{C}$ the $\mathrm{HL}$ and LL bottles were swapped over after $24 \mathrm{~h}$ in order to investigate the potential for a direct rapid effect of incubation irradiance on phytoplankton physiology (see below).

[13] For each treatment triplicate bottles were incubated and typically subsampled two times during the experiments for chlorophyll, macronutrients and biophysical active fluorescence measurements. The first time point was at $24 \mathrm{~h}$ for experiments $\mathrm{C}$ and $\mathrm{D}$ and at $48 \mathrm{~h}$ for $\mathrm{A}$ and $\mathrm{B}$. Subsampling was carried out under a class 100 laminar flow hood. At the initial and end time point, samples were also collected for phytoplankton identification and enumeration by microscopy and $\mathrm{dFe}$ to check for contamination (experiments $\mathrm{A}-\mathrm{D}$ ). For experiment $\mathrm{A}$ an additional time point after one day was taken for phytoplankton identification. No contamination was detected by postincubation $\mathrm{dFe}$ measurements in any of the bottles within our experiments. A high degree of consistency in response was found within all parameters measured in triplicate bottles. (See Table 2.)

\subsection{Dissolved Iron}

[14] Samples for dissolved iron ( $\mathrm{dFe}$ ) analysis were gently pressure filtered using $0.2 \mu \mathrm{m}$ pore size cartridge filters (Sartobran-P300, Sartorius) using nitrogen gas at 1.1 bar pressure. Samples were analyzed using an automated flow injection chemiluminescence method, following the modified Obata method [de Jong et al., 1998; Obata et al., 1993, 1997] with 8-hydroxyquinoline (8-HQ) immobilized on Toyopearl gel [Landing et al., 1986] as preconcentration/ matrix removal resin. All solutions were prepared with 18.2 $\mathrm{M} \Omega \mathrm{cm}^{-1}$ deionized water (Milli-Q, Millipore). A $179.1 \mu \mathrm{M}$ Fe standard (stock 1) was prepared on a weekly basis from a 1000 ppm AAS standard (Fisher). A $1791 \mathrm{nM}$ stock solution (stock 2) was prepared daily from stock 1 before commence of analysis.

[15] All samples were acidified to a $\mathrm{pH} 2$ with ultra pure $\mathrm{HCl}$ (Fisher Optima) and stored for a minimum of $24 \mathrm{~h}$. A $0.01 \%$ solution of $\mathrm{H}_{2} \mathrm{O}_{2}$ (Romil Upa) $\left(1 \mu \mathrm{L} \mathrm{H}_{2} \mathrm{O}_{2}\right.$ per $\mathrm{mL}$ sample) was added one hour prior to analysis to ensure all FeII present in the sample was oxidized to FeIII. The samples were buffered to a pH $4 \pm 0.5$ using $0.12 \mathrm{M}$ $\mathrm{NH}_{4}$ Ac buffer before preconcentration on the 8-HQ column. The preconcentrated iron was eluted with $0.3 \mathrm{M} \mathrm{HCl}$ (Romil Spa), and subsequently buffered up to $\mathrm{pH} 9.3 \pm 0.2$ with $\mathrm{NH}_{4} \mathrm{OH}$ and mixed with $\mathrm{H}_{2} \mathrm{O}_{2}$ and luminol to produce the chemiluminescence reaction which was detected using a photomultiplier tube (Hamatsu).

[16] Each sample was run in triplicate. The blank, was calculated from the difference in dFe concentrations between seawater samples with normal and double amounts of $\mathrm{HCl}$ and buffer added. The analytical blank varied between 0.017 and $0.042 \mathrm{nM}$ with a mean value of $0.028 \pm 0.009(\mathrm{n}=$ 13) $\mathrm{nM}$ dFe. Samples were corrected for the blank. The detection limit, calculated as $3 \times$ the standard deviation of the lowest standard addition, was on average $0.027 \pm 0.017$ $(\mathrm{n}=11) \mathrm{nM}$ dFe. SAFe [Johnson et al., 2005] and IRONAGES samples [Bowie et al., 2006] were used as reference material with an average of $0.085 \pm 0.013 \mathrm{nM}( \pm 1$ standard deviation $(\mathrm{SD}), \mathrm{n}=5)$ for $\mathrm{SAFe}$ and $0.56 \pm 0.05 \mathrm{nM}( \pm 1 \mathrm{SD}$, $\mathrm{n}=6$ ) for IRONAGES; these results agree well with the reported values.

\subsection{Chlorophyll, Taxonomic Analysis, and Nutrients}

[17] Samples for chlorophyll analysis, 100-200 mL, were filtered using $\mathrm{GF} / \mathrm{F}$ and $5 \mu \mathrm{m}$ polycarbonate filters (Whatman) to obtain size-fractionated samples and then extracted into $90 \%$ acetone for $24 \mathrm{~h}$ in the dark before analysis with a fluorometer (TD70; Turner Designs) [Welschmeyer, 1994]. Phytoplankton samples $(250 \mathrm{~mL})$ were preserved in $2 \%$ alkaline lugols iodine and subsamples were counted ashore using light microscopy [Poulton et al., 2007]. 
[18] Macronutrients (nitrate + nitrite, hereafter nitrate, phosphate and orthosilicic acid) were analyzed on board during the first leg of the cruise using standard colorimetric techniques on an autoanalyzer (Skalar San Plus) [Sanders and Jickells, 2000].

[19] Samples were drawn directly from Niskin bottles into polystyrene vials and stored at $4{ }^{\circ} \mathrm{C}$ until analysis, which commenced within $12 \mathrm{~h}$ of sampling. Consistency of the data was ensured by the analysis of commercial nutrient standards (Ocean Scientific International, United Kingdom), at regular intervals on the cruise and by the comparison of deep water nutrient concentrations between stations. In addition, nutrients were analyzed in samples collected from the ship's underway supply. Detection limits were $0.1 \mu \mathrm{M}$ for $\mathrm{N}$ and $\mathrm{Si}$ and $0.02 \mu \mathrm{M}$ for P. Blanks were $0.05 \mu \mathrm{M}$ for $\mathrm{N}$ and $\mathrm{Si}$ and $0.01 \mu \mathrm{M}$ for P.

[20] On the second leg of the cruise nutrient analysis was carried out with a flow injection autoanalyzer (Lachat Quick Chem 800) using the manufacturers recommended methods. Samples were measured in triplicate to identify instrument precision. Standards were prepared in deionized water and the samples were run in a carrier stream of deionized water. The matrix effect which results from the difference in ionic strength between seawater and deionized water was corrected for by running a number of low-nutrient sea water samples (Ocean Scientific International, Batch LNS 16, Salinity 35) during each sample batch run and the mean result was subtracted from the sample result. Nitrate levels in this are less than $0.1 \mu \mathrm{M}$, the detection limit of our system.

\subsection{Active Chlorophyll Fluorescence}

[21] The photosystem II photochemical efficiency $\left(\mathrm{F}_{\mathrm{v}} / \mathrm{F}_{\mathrm{m}}\right)$ was assessed via chlorophyll fluorescence measurements performed using both fast repetition rate fluorometer (FRRF) (Chelsea Scientific Instruments) [Kolber et al., 1998] and Fluorescence Induction and Relaxation (FIRe) (Satlantic) fluorometers [Bibby et al., 2008]. Subsampling of bioassays occurred within the latter half of the night period, i.e., between local midnight and dawn, with subsamples then being kept in the dark at in situ temperature for 30-90 min before measurement. Filtrates were analyzed for all discrete samples in order to allow correction for the blank [Cullen and Davis, 2003]. Corrections for instrument response and (inter-) calibrations of fluorescence yields were performed using extracts of chlorophyll $a$. Protocols for FRRF measurements are detailed elsewhere [Moore et al., 2005, 2006, 2007]. Fluorescence transients from the FIRe instrument were fitted to the model of Kolber et al. [1998] using custom software written in MATLAB ${ }^{\mathrm{TM}}$. All discrete samples were run on both instruments and were highly comparable once all artifacts associated with instrument responses and blanks were accounted for. For simplicity discrete sample results are only presented for the FRRF. An additional FRRF was connected in line with the ships underway sampling system.

\section{Results and Discussion}

3.1. Surface Chlorophyll, Nutrients, dFe, and Photochemical Efficiency

[22] The Sea-viewing Wide Field-of-view Sensor (SeaWiFS) monthly chlorophyll composite for August 2007 indicated enhanced chlorophyll concentrations $(>1 \mathrm{mg}$ $\mathrm{m}^{-3}$ ) in conjunction with shallow topography, particularly on the Iceland shelf, along with some additional enhanced chlorophyll concentrations in a broad region marking the boundary of the Irminger and Iceland Basins over the Reykjanes Ridge (Figure 1a). In the central Iceland Basin, satellite derived chlorophyll concentrations averaged $\sim 0.4 \mathrm{mg} \mathrm{m}^{-3}$ (Figure 1a), consistent with our own measurements of the in situ surface chlorophyll concentration, which ranged from 0.2 to $0.4 \mathrm{mg} \mathrm{m}^{-3}$. SeaWiFS data further indicated that chlorophyll concentrations in the central Iceland Basin were persistently $<0.5 \mathrm{mg} \mathrm{m}^{-3}$ throughout the summer months of July-September 2007. Surface nitrate concentrations in the southerly central Iceland Basin ranged from 2 to $5 \mu \mathrm{M}$ and phosphate ranged from $\sim 0.1$ to $0.4 \mu \mathrm{M}$. When combined with the persistent low postbloom chlorophyll concentrations these data suggest the development of HNLC conditions in the central Iceland Basin in summer.

[23] Surface $d F e$ concentrations in the central Iceland Basin ranged from $<0.010$ to $0.218 \mathrm{nM}$, with an average of $0.093(n=43) n M$. The higher $\mathrm{dFe}$ values appeared to be associated with an anticyclonic mode water eddy. Measures et al. [2008] observed similar low concentrations of dFe in surface waters, with an average of $0.09 \mathrm{nM}$ (range 0.02 to $0.16 \mathrm{nM}$ ) alongside $\sim 5 \mu \mathrm{M}$ nitrate in this region in June 2003 , i.e., around a month earlier than our cruise. Such observations of low dFe concentrations and low chlorophyll along with residual nitrate concentrations suggest that iron limitation may contribute to the observed seasonal HNLC condition.

[24] Underway measurements of $F_{v} / F_{m}$ indicated marked diel signals with low daytime values and a postdawn maximum. The latter presumably represents the maximal photochemical efficiencies for the in situ population [Behrenfeld et al., 2006]. Highest values of postdawn $\mathrm{F}_{\mathrm{v}} / \mathrm{F}_{\mathrm{m}}$ approached 0.6 and were associated with the enhanced chlorophyll concentrations over the Iceland shelf (Figure $1 \mathrm{~b}$ ). In contrast $\mathrm{F}_{\mathrm{v}} / \mathrm{F}_{\mathrm{m}}$ values within the central Iceland Basin were persistently $<0.4$ (Figure 1b). Higher $\mathrm{F}_{\mathrm{v}} / \mathrm{F}_{\mathrm{m}}$ associated with high-chlorophyll shelf waters was consistent with enhanced iron availability near shallow bathymetry, as also observed in the Southern Ocean [Moore et al., 2007].

[25] However, care must be taken not to over interpret such gradients in $\mathrm{F}_{\mathrm{v}} / \mathrm{F}_{\mathrm{m}}$ in the context of nutrient stress [Moore et al., 2005]. In particular, taxonomic groups can exhibit different maximal values of $\mathrm{F}_{\mathrm{v}} / \mathrm{F}_{\mathrm{m}}$ likely resulting in spatial variability in photochemical efficiencies at least partially reflecting changes in community structure [Moore et al., 2005; Suggett et al., 2009]. We thus performed nutrient manipulation experiments to asses the potential for increased iron availability to directly influence phytoplankton physiology [Greene et al., 1994].

\subsection{Incubation Experiments: Initial Conditions and Physiological Response}

[26] Incubation experiments were all initiated in waters with $2.8-5 \mu \mathrm{M}$ residual nitrate concentrations (Table 1). Initial chlorophyll concentrations ranged from 0.2 to $0.4 \mathrm{mg}$ $\mathrm{m}^{-3}$ for the three experiments $(\mathrm{A}-\mathrm{C})$ undertaken in the central Iceland Basin, to $\sim 0.6 \mathrm{mg} \mathrm{m}^{-3}$ for the northerly 
Table 1. Initial Conditions for the Bioassay Experiments ${ }^{\mathrm{a}}$

\begin{tabular}{|c|c|c|c|c|}
\hline & Experiment A & Experiment B & Experiment $\mathrm{C}$ & Experiment D \\
\hline Sampling date & 7 Aug. & 14 Aug. & 15 Aug. & 27 Aug. \\
\hline Latitude $\left({ }^{\circ} \mathrm{N}\right)$ & $59-42.66$ & $59-12.57$ & $58-52.13$ & $62-55.20$ \\
\hline Longitude $\left({ }^{\circ} \mathrm{W}\right)$ & $18-45.09$ & $19-53.59$ & $20-22.03$ & $19-32.90$ \\
\hline Sample depth (m) & 10 & 10 & 3 & 3 \\
\hline MLD (m) & 28 & 20 & 35 & 39 \\
\hline $\mathrm{K}_{\mathrm{d}}\left(\mathrm{m}^{-1}\right)$ & 0.08 & 0.09 & 0.13 & 0.11 \\
\hline $\mathrm{E}_{\mathrm{avg}}\left(\% \mathrm{E}_{0}\right)$ & 41.18 & 46.24 & 21.91 & 22.85 \\
\hline $\operatorname{SST}\left({ }^{\circ} \mathrm{C}\right)$ & 13.47 & 13.24 & 13.0234 & 12.134 \\
\hline $\mathrm{dFe}(\mathrm{nM})$ & $0.17( \pm 0.12)$ & $0.37( \pm 0.03)$ & $0.05( \pm 0.01)$ & $0.15( \pm 0.06)$ \\
\hline Nitrate $(\mu \mathrm{M})$ & $3.27( \pm 0.02)$ & $5.00( \pm 0.02)$ & $2.88( \pm 0.03)$ & $2.83( \pm 0.33)$ \\
\hline Silicic acid $(\mu \mathrm{M})$ & $0.33( \pm 0.01)$ & $0.70( \pm 0.01)$ & $0.35( \pm 0.01)$ & $0.03( \pm 0.02)$ \\
\hline $\operatorname{Chl}\left(\mathrm{mg} \mathrm{m}^{-3}\right)$ & $0.24( \pm 0.01)$ & $0.39( \pm 0.02)$ & $0.37( \pm 0.01)$ & $0.58( \pm 0.14)$ \\
\hline $\mathrm{Chl}>5 \mu \mathrm{m}\left(\mathrm{mg} \mathrm{m}^{-3}\right)$ & $0.03( \pm 0.00)$ & $0.06( \pm 0.00)$ & $0.053( \pm 0.01)$ & ND \\
\hline $\mathrm{Chl}<5 \mu \mathrm{m}\left(\mathrm{mg} \mathrm{m}^{-3}\right)$ & $0.20( \pm 0.00)$ & $0.33( \pm 0.03)$ & $0.320( \pm 0.01)$ & ND \\
\hline $\mathrm{F}_{\mathrm{v}} / \mathrm{F}_{\mathrm{m}}$ & $0.36( \pm 0.00)$ & $0.33( \pm 0.00)$ & $0.28( \pm 0.00)$ & $0.40( \pm 0.02)$ \\
\hline
\end{tabular}

${ }^{a}$ Shown are mean values $( \pm 1 \mathrm{SE})$ for triplicate initial samples. MLD, mixed layer depth; $\mathrm{K}_{\mathrm{d}}$, diffuse attenuation coefficient for photosynthetically available radiation PAR; $\mathrm{E}_{\text {avg }}$, mean irradiance expresses as percent of the surface irradiance $\mathrm{E}_{\mathrm{o}}$; SST, sea surface temperature; Chl, chlorophyll $a$; ND, not determined.

experiment (D) initiated closer to the Iceland shelf. Consistent with transect data (Figure $1 \mathrm{~b}$ ), higher initial values of $\mathrm{F}_{\mathrm{v}} / \mathrm{F}_{\mathrm{m}}$ were observed in the northerly experiment (D) (Table 1). Initial concentrations of $\mathrm{dFe}$ were $<0.1 \mathrm{nM}$ for 2 of the southerly experiments (A and $\mathrm{C}$ ), with a higher initial concentrations for experiment B initiated within the mode water eddy.

[27] The composition of the phytoplankton community varied between experiments. The initial abundances of the coccolithophore Emiliania huxleyi ranged from 130 to 270 cells $\mathrm{mL}^{-1}$ for all experiments. The centric diatom species Proboscia alata and Lauderia annulata dominated diatom biomass for the northerly experiment (D) toward the Iceland shelf. In contrast, Cylindrotheca closterium typically dominated diatom biomass within the southerly experiments $(\mathrm{A}-\mathrm{C})$. Mixed layer depths were shallow, ranging from $\sim 20-40 \mathrm{~m}$. Combined with relatively low-irradiance attenuation (Table 1), the shallow MLD resulted in mean irradiances of $\sim 20-40 \%$ of the surface value within the mixed layer (Table 1). Consequently LL treatments approximated irradiances at the base of the mixed layer while HL treatments approximated mean mixed layer irradiances.

[28] Despite some variability in initial conditions, a rapid physiological response to iron addition was observed (after $<24$ or $48 \mathrm{~h}$ ) in all experiments (Figure 2). Values of $\mathrm{F}_{\mathrm{v}} / \mathrm{F}_{\mathrm{m}}$ in iron amended treatments were in all cases significantly higher than controls (ANOVA, Tukey-Kramer means comparison test, $\mathrm{p}<0.05)$. However, physiological responses to different light levels and throughout the time course of the experiments were complex (Figures 3-5). In particular, $\mathrm{F}_{\mathrm{v}} / \mathrm{F}_{\mathrm{m}}$ in $\mathrm{HL}$ treatments typically decreased with time relative to corresponding LL treatments, irrespective of iron addition (Figure 4), potentially representing accumulation of long-lived photoinhibitory damage to PSII [Kolber et al., 1994; Moore et al., 2007]. Irrespective of the precise mechanism, the swap between HL and LL treatments after $24 \mathrm{~h}$ within experiment $\mathrm{C}$ confirmed the rapid physiological nature of this response (not shown).

[29] Furthermore, for southerly experiments $(\mathrm{A}-\mathrm{C})$, initial (predawn) in situ values of $\mathrm{F}_{\mathrm{v}} / \mathrm{F}_{\mathrm{m}}$ (Table 1) were lower than subsequent values measured within controls (Table 1 and Figure 2). This rapid divergence of controls and in situ values can be speculated to result from a number of mechanisms. For example, increased photoinhibition may potentially occur in situ within the shallow mixed layers, particularly in the low attenuation southerly region (i.e., experiments $\mathrm{A}-\mathrm{C}$ ), where peak (surface) irradiances and UV exposure [Vassiliev et al., 1994] likely exceeded those within high-light incubations. Alternatively, the lack of the effect within the potentially more Fe replete northerly population (D) may suggest a low level of Fe contamination, which was only detectable from the biological response within southerly experiments $(\mathrm{A}-\mathrm{C})$. However, the differing response between experiments $\mathrm{A}-\mathrm{C}$ and $\mathrm{D}$ may also be linked to the contrasting community structure.

[30] Overall, despite the potential complexities resulting from variable irradiance regimes, physiological responses (Figures 2, 4b, and 5b) were comparable to similar experiments performed within the HNLC eastern equatorial Pacific [Greene et al., 1994] and Southern Ocean [Moore et al., 2007]. Rapid responses of $\mathrm{F}_{\mathrm{v}} / \mathrm{F}_{\mathrm{m}}$ to iron amendment also occur in iron starved cultures [Greene et al., 1992] and have consistently been observed in purposeful in situ iron enrichment experiments in HNLC regions [Boyd et al., 2001; Gervais et al., 2002].

[31] Although some form of "bottle effect" was clearly evidenced by the rapid divergence of in situ and control values (Figures $4 \mathrm{~b}$ and $5 \mathrm{~b}$ ), biophysical parameters such as $\mathrm{F}_{\mathrm{v}} / \mathrm{F}_{\mathrm{m}}$ should be independent of differences in grazing between the in situ population and those constrained within bottles [Cullen, 1991]. Consequently our bioassay experiments provided unequivocal evidence of physiological iron stress within at least a proportion of the natural community [Greene et al., 1994; Kolber et al., 1994].

\subsection{Incubation Experiments: Biomass, Nutrient Drawdown, and Species Response}

[32] For the southerly (central Iceland Basin) experiments (A-C), chlorophyll increased above initial concentrations in the control bottles and, for a given light level, chlorophyll was significantly higher in the iron amended bottles than controls. Final chlorophyll concentrations in iron-amended 

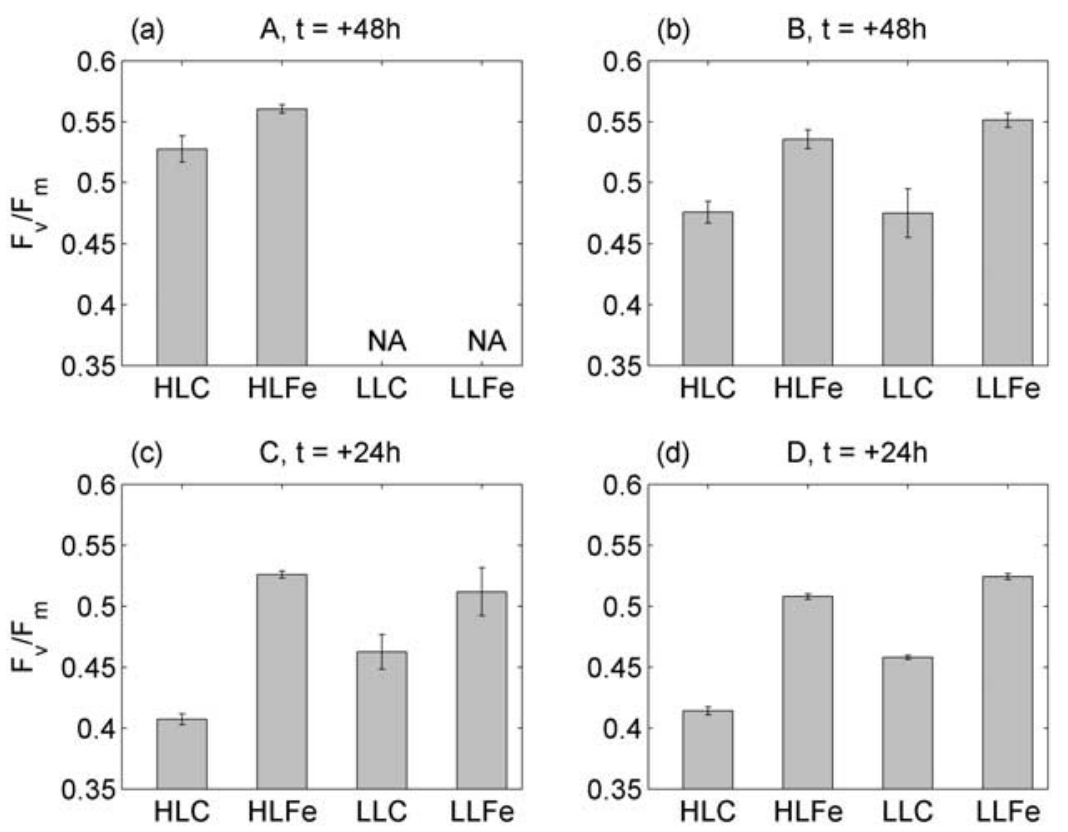

Figure 2. Differences between $\mathrm{F}_{\mathrm{v}} / \mathrm{F}_{\mathrm{m}}$ in controls and iron-amended treatments for the four bioassay experiments at the first time point. Here ( $a$ and $b) t=48 h$ for experiments $A$ and $B$ and $(c$ and $d) t=24 h$ for experiments $C$ and D. Shown are means ( \pm 1 standard error $(\mathrm{SE}), \mathrm{n}=3)$. NA, not available.

bottles were 1.5-2 fold larger than those of the control bottles after 5-6 days for all the southerly experiments (AC). Net growth rates $\left(\mu_{\text {net }}\right)$ calculated from total chlorophyll accumulation were thus around 1.5-2 fold higher under iron amendment (Table 1). The $<5 \mu \mathrm{m}$ fraction constituted $>80 \%$ of the total chlorophyll under initial conditions for central Iceland Basin experiments (Table 1). For all size fractions $\mu_{\text {net }}$ was higher in iron amended treatments than the controls (Table 2). In contrast, for the northerly experiment (D), no significant increase in chlorophyll was observed in any treatment except LLFe (Table 2).

[33] Responses of individual phytoplankton taxa to experimental manipulations varied. The coccolitophore Emiliania huxleyi showed a positive response in all experiments. In particular $\mu_{\text {net }}$ for E. huxleyi increased from $\sim 0$ to $0.27 \mathrm{~d}^{-1}$ for experiment A (Figure 3). Cylindrotheca closterium also increased in abundance within HLC for all experiments, with an average HLC $\mu_{\text {net }}=0.35 \pm 0.05 \mathrm{~d}^{-1}$ compared to an average LLC values of $0.03 \pm 0.06 \mathrm{~d}^{-1}$. Furthermore, there was an additional increase in abundance of this species in response to iron amendment compared to the controls (Figure 3c).

[34] Chlorophyll accumulation was higher under Fe amended conditions for the larger $(>5 \mu \mathrm{m})$ size fraction within all the experiments where measurements were made (A-C) $(\mathrm{P}<0.05$, ANOVA, Tukey). However, the $<5 \mu \mathrm{m}$ fraction also responded to $\mathrm{Fe}$ amendment, with significant differences observed for experiments $\mathrm{B}-\mathrm{C}(\mathrm{P}<0.05$, ANOVA, Tukey). HL and LL treatments also differed within experiment $\mathrm{B}$, with chlorophyll accumulation in the HLFe treatments being higher than LLFe for both size classes, while HLC and LLC were only significantly different in the larger size class $(\mathrm{P}<0.05$, ANOVA, Tukey). In contrast, differences between light treatments were not significant within experiment $\mathrm{C}$.

[35] To our knowledge a strong response of natural $E$. huxleyi communities to iron addition has rarely been reported and indeed coccolithophores have typically been assumed to be strong competitors at low iron [Zondervan, 2007]. However, Crawford et al. [2003] reported a similar response for the subarctic HNLC Pacific [Crawford et al., 2003]. Our bioassays thus indicated the potential for iron limitation of both large $(>5 \mu \mathrm{m})$ and small $(<5 \mu \mathrm{m})$ phytoplankton groups including $E$. huxleyi within postbloom conditions in the central Iceland Basin.

[36] Significant differences in macronutrient drawdown between treatments were observed in all experiments. For experiment $\mathrm{B}$ where initial silicic acid concentrations were $\sim 0.7 \mu \mathrm{M}$, significant drawdown was observed under both HL conditions. However, drawdown was more rapid for the HLFe treatment (Figure 4d). For all the central Iceland Basin experiments $(\mathrm{A}-\mathrm{C})$, enhanced nitrate and phosphate drawdown (not shown) in iron amended bottles was observed under both HL and LL treatments (Figures 3 and 4 and Table 2). Complete drawdown of nitrate was observed within both HL treatments over the duration of the northerly experiment (D), with the rate of drawdown being marginally higher the first 4 days within the HLFe bottles (Figure 5). For all experiments, higher drawdown of both nitrate and phosphate was observed in HL compared to LL treatments. However, light levels were unlikely to have been restricting nutrient drawdown in situ, as mean mixed layer irradiances were equal to, and peak levels higher than, our HL treatments.

[37] Using the data of [Ho et al., 2003; Sunda and Huntsman, 1995; Twining et al., 2004b], we estimate that 
(a)

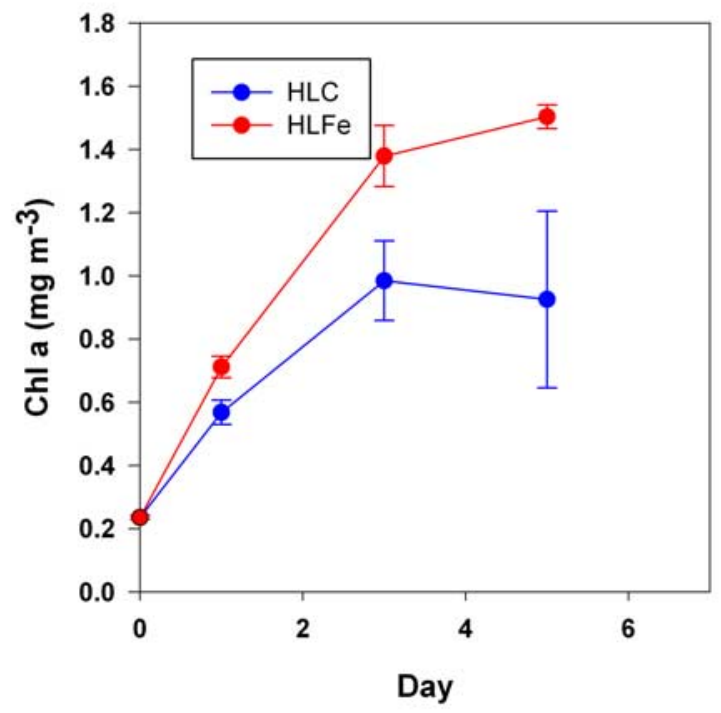

(c)

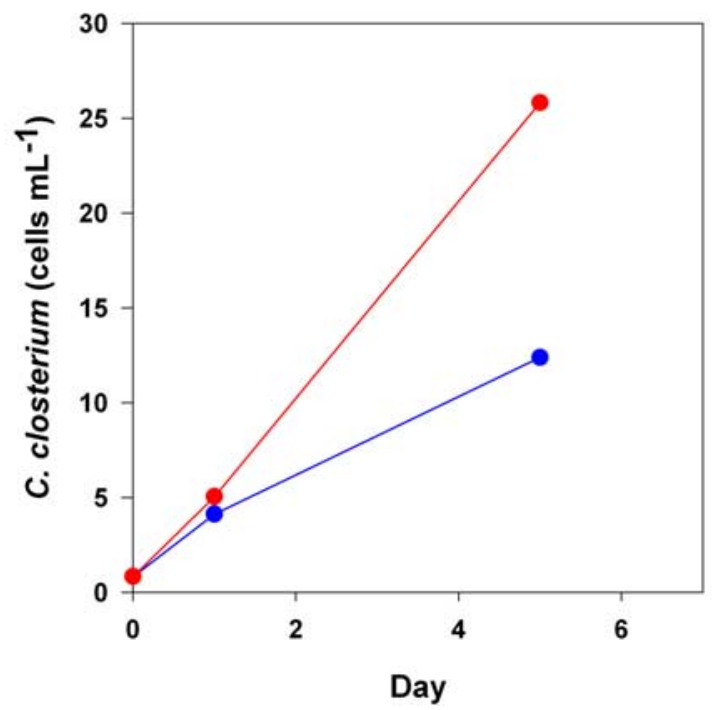

(b)

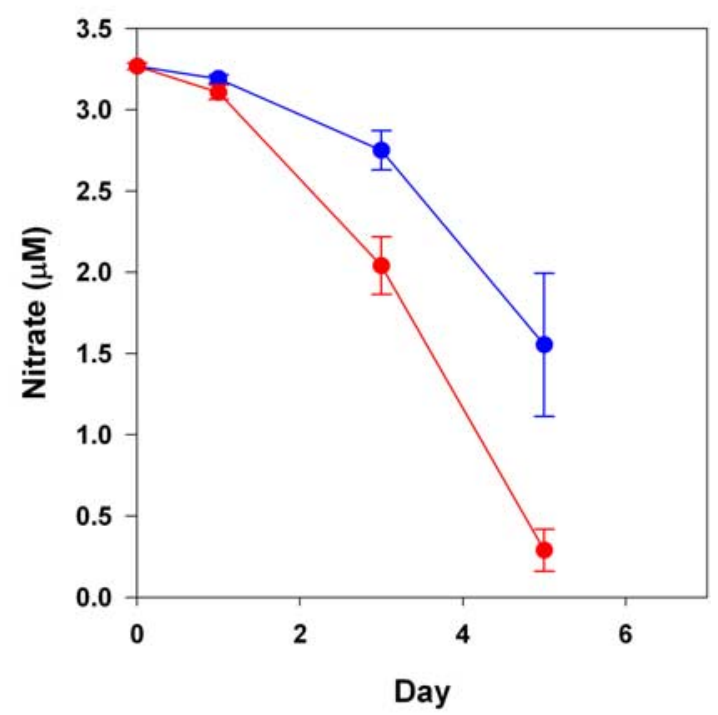

(d)

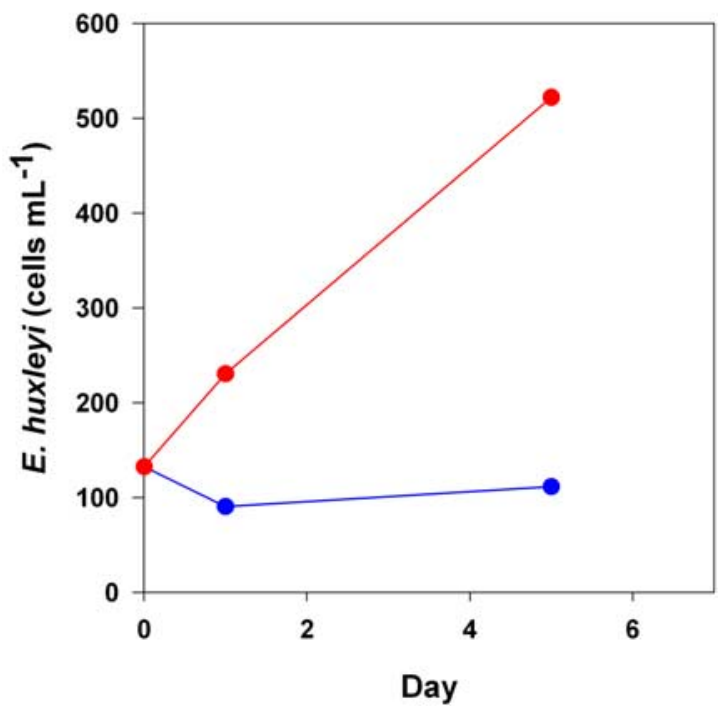

Figure 3. Results of bioassay experiment A. (a) Chlorophyll concentration against time and (b) nitrate concentration against time. Shown are mean values $( \pm 1 \mathrm{SE}, \mathrm{n}=3$ ). (c) Plot of the abundance of the diatom C. closterium and (d) the coccolitophore E.huxleyi against time. Shown are counts of one sample per condition.

cellular Fe:N ratios of $<0.02 \mathrm{mmol} / \mathrm{mol}$ are growth rate limiting even for oceanic taxa including E. huxleyi. Postbloom surface $\mathrm{dFe}: \mathrm{NO}_{3}^{-}$ratios were frequently lower than this value in the central Iceland Basin. In particular, starting $\mathrm{dFe}: \mathrm{NO}_{3}^{-}$ratios were $<0.02$ for 2 of our three southerly experiments (Table 1). Consequently, (continued) development of iron limitation could be predicted as biomass increased within the bottles. However, interpretation of chlorophyll accumulation or nutrient drawdown within such experiments must be treated with caution because of poten- tial unrealistic ecosystem dynamics [Cullen, 1991; Geider and La Roche, 1994]. Potential reductions in loss terms, including grazing, sinking and advection will all increase net growth in bottles. Indeed, within HL controls approximating mean in situ light conditions, significant drawdown of residual macronutrients, along with accumulation of chlorophyll and some phytoplankton groups, was observed in all our experiments (Figures 3 and 4 and Table 2).

[38] Consequently we cannot discount intense grazing as a contributing factor to postbloom HNLC conditions 
(a)

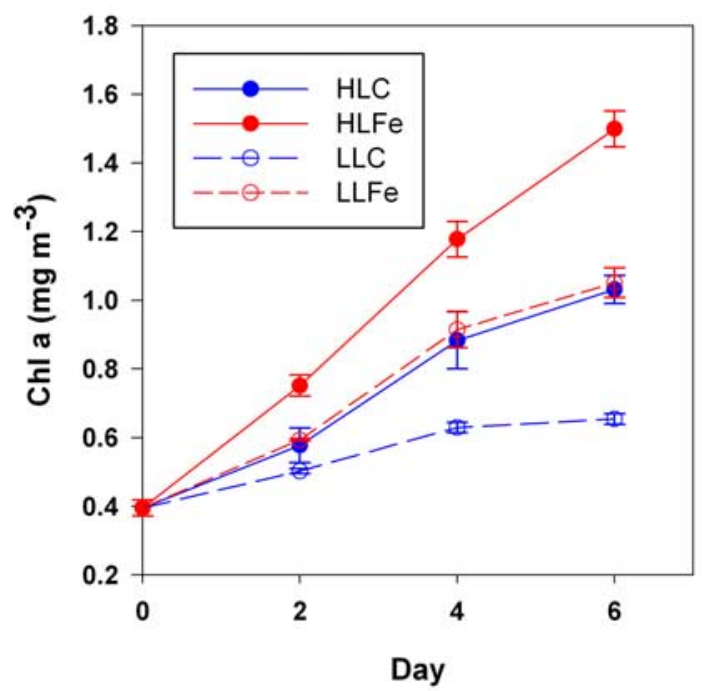

(c)

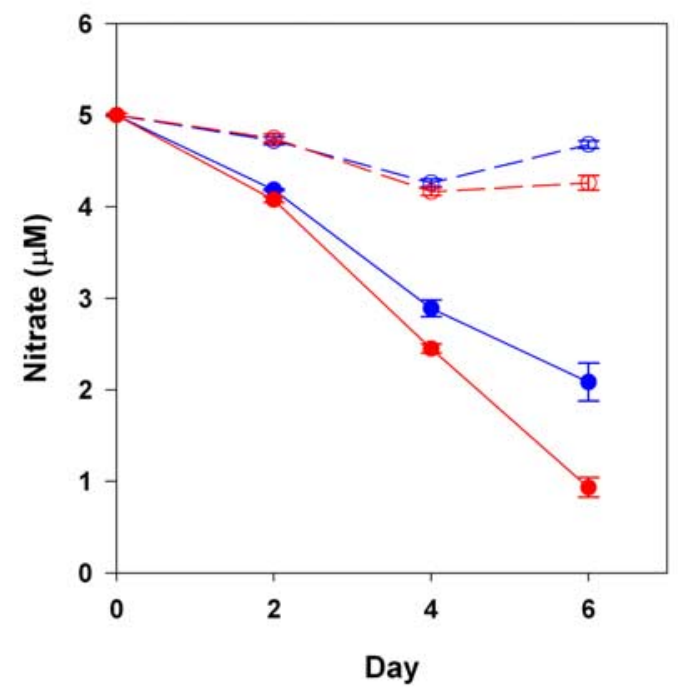

(b)

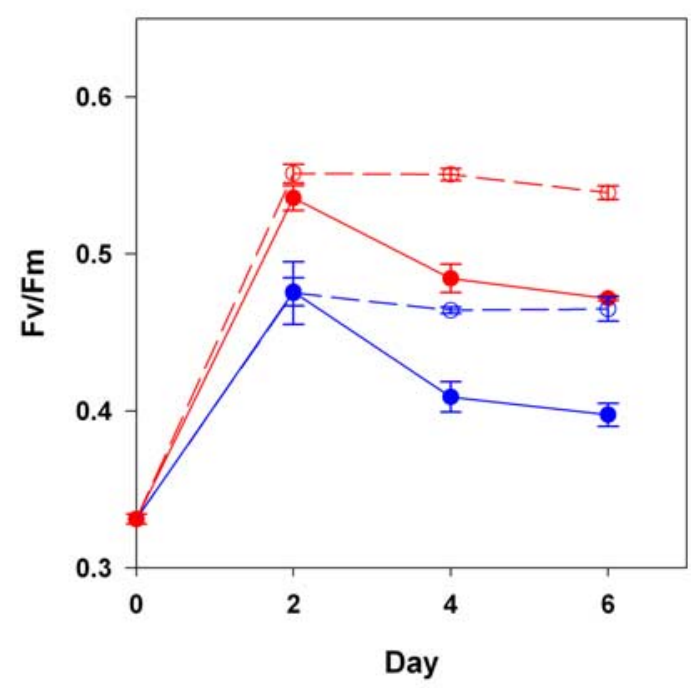

(d)

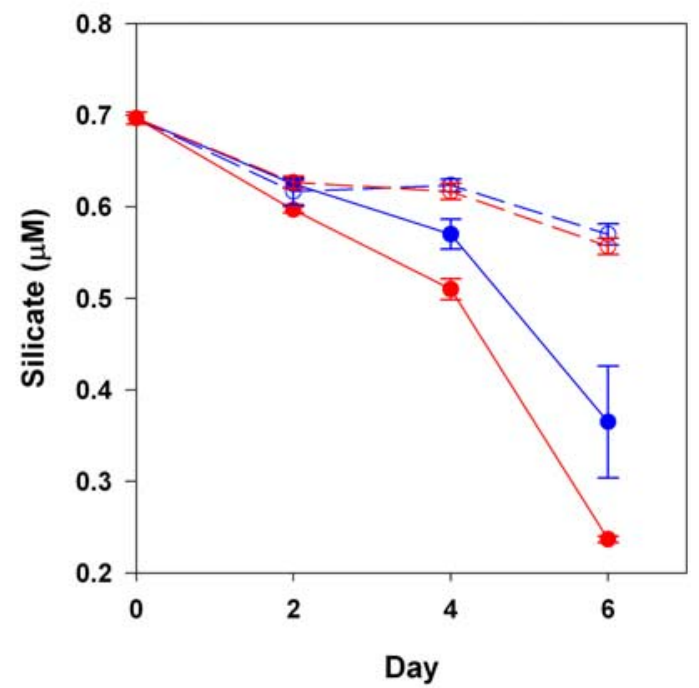

Figure 4. Results of bioassay experiment B. (a) Chlorophyll concentration, (b) $\mathrm{F}_{\mathrm{v}} / \mathrm{F}_{\mathrm{m}}$, (c) nitrate concentration, and (d) silicate concentration against time. Shown are mean values $( \pm 1 \mathrm{SE}, \mathrm{n}=3)$.

[Banse, 2002; Cullen, 1991; Frost, 1991; Morel et al., 1991; Price et al., 1994]. However, along with consistently enhanced biomass accumulation and macronutrient drawdown in iron amended treatments in southerly experiments, the low ambient $\mathrm{dFe}$ concentrations and rapid response of biomass/grazing-independent physiological variables combined to strongly suggest that iron availability influences phytoplankton growth during postbloom conditions in the central Iceland Basin.

[39] Despite a clear physiological response (Figure 2d), weaker biomass increases and complete nutrient drawdown in HL treatments for the northerly experiment (D) supports the suggestion of a more iron replete community in this region closer to shallow bathymetry (Figure 1a). For this experiment, increased bulk chlorophyll accumulation in
LLFe treatments only may indicate an increased ability to acclimate to lower than in situ light levels under conditions of higher iron availability [Raven, 1990; Sunda and Huntsman, 1997].

\subsection{Potential for an Iron-Limited HNLC Postbloom Condition}

[40] Considerable mesoscale variability below the mixed layer was observed in depth profiles of $\mathrm{dFe}$ in the central Iceland Basin ( $\mathrm{dFe}$ profiles and associated data for this region are presented in Table 3 ). We thus consider average vertical profiles of $\mathrm{dFe}$ and nitrate constructed from the data collected in the central Iceland Basin (Figure 6). DFe concentrations in the surface averaged around $0.1 \mathrm{nM}$ and similar low values were observed throughout and immedi- 
(a)

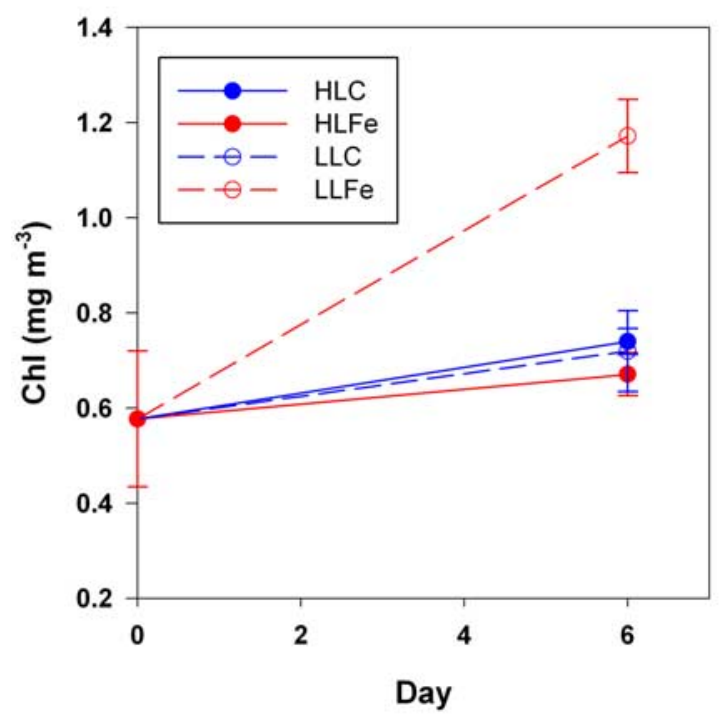

(c)

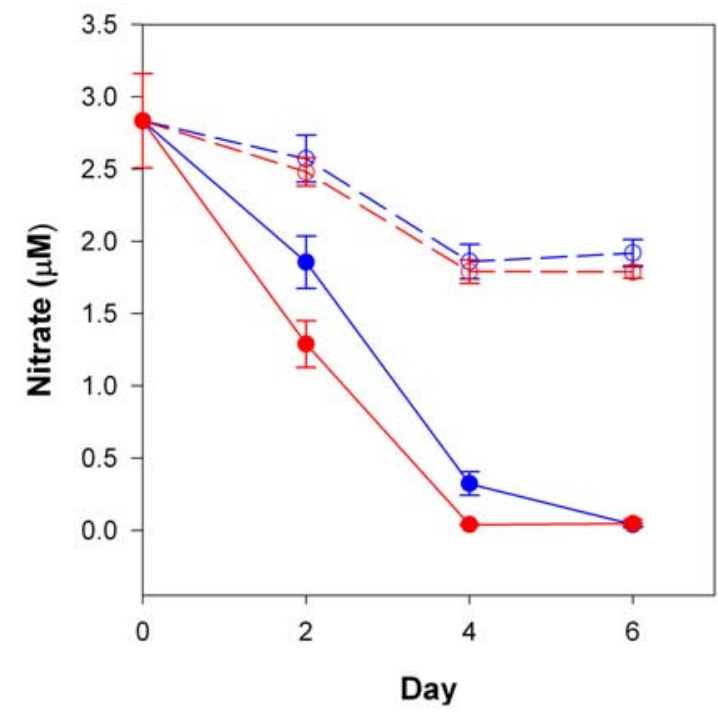

(b)

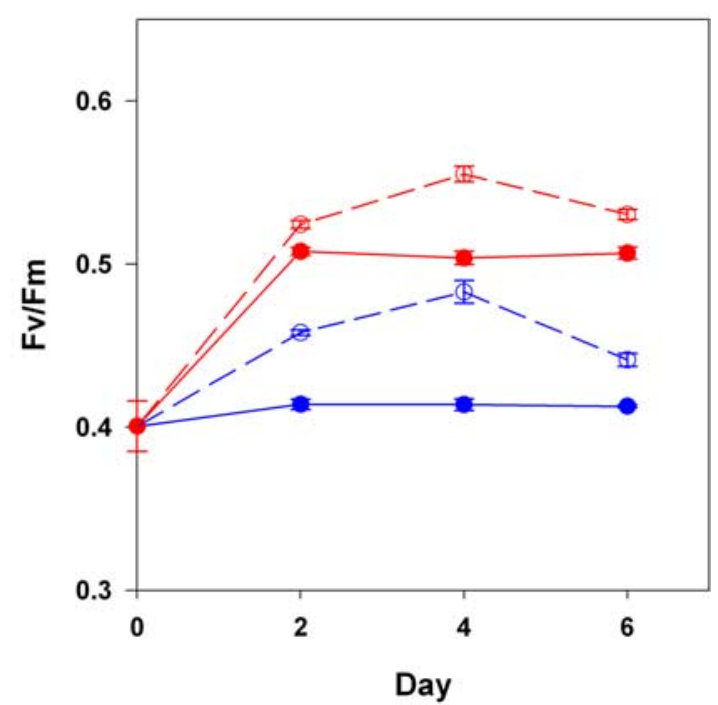

Figure 5. Results from bioassay experiment D. (a) Chlorophyll concentration at day zero and end point, (b) $\mathrm{F}_{\mathrm{v}} / \mathrm{F}_{\mathrm{m}}$, and (c) nitrate concentration against time. Shown are mean values $( \pm 1 \mathrm{SE}, \mathrm{n}=3)$.

ately below the mixed layer. Concentrations of $\mathrm{dFe}$ increased with depth to around $0.4 \mathrm{nM}$ within mode waters between $\sim 400-600 \mathrm{~m}$ and $>0.6 \mathrm{nM}$ for depths $>1000 \mathrm{~m}$. These concentrations are consistent with previous observations in the area [Johnson et al., 1997; Martin et al., 1993; Measures et al., 2008]. Detailed hydrographic data indicated that deepest winter mixing penetrated to around 800 $\mathrm{m}$ in our study region. In addition to providing the macronutrients to fuel the spring bloom, deep winter mixing will also input dissolved iron into surface waters. The $\mathrm{dFe}: \mathrm{NO}_{3}^{-}$ ratio was $<0.05 \mathrm{mmol} / \mathrm{mol}$ at depth down to $800 \mathrm{~m}$ (Figure 6d) and hence the ratio of $\mathrm{Fe}$ to $\mathrm{N}$ input during winter overturning will similarly be $<0.05 \mathrm{mmol} / \mathrm{mol}$. Cellular Fe:N ratios for iron replete phytoplankton range

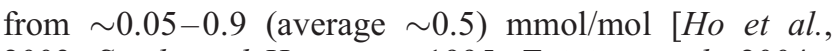
2003; Sunda and Huntsman, 1995; Twining et al., 2004a, 2004b]. Consequently, winter overturning inputs of $\mathrm{NO}_{3}^{-}$to the surface waters of the central Iceland Basin will not be accompanied by sufficient dissolved iron to satisfy complete macronutrient removal by iron replete phytoplankton growth, a situation which also occurs in classical HNLC regions [Boyd et al., 2000; Hutchins and Bruland, 1998; Martin and Fitzwater, 1988].

[41] Assuming that mode waters $(\sim 400-600 \mathrm{~m})$ are representative of end of winter conditions, prebloom surface $\mathrm{dFe}$ concentrations would have been $\sim 0.4 \mathrm{nM}$. Alternatively, integrating our mean $\mathrm{dFe}$ profile from the maximum depth of winter mixing to the surface yields an estimated 
Table 2. High-Light Control, High-Light Fe, Low-Light Control, and Low-Light Fe for the Bioassay Experiments ${ }^{\mathrm{a}}$

\begin{tabular}{|c|c|c|c|c|c|}
\hline & & $\Delta \mathrm{NO}_{3}^{-}(\mu \mathrm{M})$ & $\mu^{\mathrm{Chl}}\left(\mathrm{d}^{-1}\right)$ & $\mu^{\mathrm{Chl}}>5 \mu \mathrm{m}\left(\mathrm{d}^{-1}\right)$ & $\mu^{\mathrm{Chl}}<5 \mu \mathrm{m}\left(\mathrm{d}^{-1}\right)$ \\
\hline \multirow[t]{2}{*}{ Experiment A } & HLC & $1.71( \pm 0.44)$ & $0.22( \pm 0.06)$ & $0.28( \pm 0.02)$ & $0.23( \pm 0.08)$ \\
\hline & HLFe & $2.98( \pm 0.13)$ & $0.32( \pm 0.00)$ & $0.37( \pm 0.01)$ & $0.36( \pm 0.01)$ \\
\hline \multirow[t]{4}{*}{ Experiment B } & HLC & $2.92( \pm 0.21)$ & $0.29( \pm 0.01)$ & $0.30( \pm 0.03)$ & $0.11( \pm 0.00)$ \\
\hline & HLFe & $4.07( \pm 0.11)$ & $0.32( \pm 0.00)$ & $0.35( \pm 0.02)$ & $0.18( \pm 0.01)$ \\
\hline & LLC & $0.32( \pm 0.04)$ & $0.21( \pm 0.06)$ & $0.16( \pm 0.01)$ & $0.06( \pm 0.01)$ \\
\hline & LLFe & $0.74( \pm 0.08)$ & $0.31( \pm 0.00)$ & $0.22( \pm 0.00)$ & $0.15( \pm 0.01)$ \\
\hline \multirow[t]{4}{*}{ Experiment $\mathrm{C}$} & HLC & $1.22( \pm 0.09)$ & $0.13( \pm 0.05)$ & $0.24( \pm 0.02)$ & $0.10( \pm 0.02)$ \\
\hline & HLFe & $2.08( \pm 0.50)$ & $0.23( \pm 0.25)$ & $0.35( \pm 0.06)$ & $0.19( \pm 0.04)$ \\
\hline & LLC & $0.11( \pm 0.06)$ & $0.08( \pm 0.02)$ & $0.15( \pm 0.01)$ & $0.07( \pm 0.01)$ \\
\hline & LLFe & $0.74( \pm 0.08)$ & $0.21( \pm 0.02)$ & $0.29( \pm 0.01)$ & $0.19( \pm 0.01)$ \\
\hline \multirow[t]{4}{*}{ Experiment D } & HLC & $2.79( \pm 0.01)$ & $0.05( \pm 0.01)$ & ND & ND \\
\hline & $\mathrm{HLFe}$ & $2.79( \pm 0.03)$ & $0.03( \pm 0.01)$ & ND & ND \\
\hline & LLC & $0.92( \pm 0.09)$ & $0.04( \pm 0.02)$ & ND & ND \\
\hline & LLFe & $1.05( \pm 0.04)$ & $0.14( \pm 0.01)$ & ND & ND \\
\hline
\end{tabular}

${ }^{a}$ Nitrate drawdown, total growth rate, and size fractionated growth rates at the end of each bioassay experiments $\mathrm{A}-\mathrm{D}(\mathrm{t}=5-6$ days). Shown are mean values $( \pm 1 \mathrm{SE})$ of triplicate end point bottles. ND, not determined.

winter $\mathrm{dFe}$ concentration of $\sim 0.3 \mathrm{nM}$. These values are again consistent with previous estimates [Measures et al., 2008]. Similarly, end of winter surface nitrate concentrations would have been around $12 \mu \mathrm{M}$ (Figure 6). Taking the most conservative values for cellular Fe:N ratios under iron replete growth [Ho et al., 2003; Sunda and Huntsman, 1995] and average mixed layer depths of 30-40 $\mathrm{m}$ over the growth period, potential annual new production of $360-$ $480 \mathrm{mmol} \mathrm{N} \mathrm{m}^{-2} \mathrm{a}^{-1}$ would require a minimum $18-$ $24 \mu \mathrm{mol} \mathrm{Fe} \mathrm{m}^{-2} \mathrm{a}^{-1}$, with actual requirements likely to be considerably higher.

[42] Winter mixing would only input $12-16 \mu \mathrm{mol} \mathrm{Fe}$ $\mathrm{m}^{-2} \mathrm{a}^{-1}$ (Figure 6). Measured surface water dissolved aluminum concentrations in the region were low (1-3 nM; E. P. Achterberg, unpublished data, 2007), consistent with previous observations [Measures et al., 2008] and suggestive of low atmospheric iron inputs. We estimate following [Measures et al., 2008] that atmospheric inputs of iron would likely have been around $5 \mu \mathrm{mol} \mathrm{Fe} \mathrm{m}^{-2} \mathrm{a}^{-1}$ and hence an overall deficit of iron relative to $\mathrm{NO}_{3}^{-}$is likely to remain, even accounting for this term and ignoring any nitrate which may be deposited from the atmosphere.

[43] Our data therefore confirm that the supply of iron from winter overturning in the central Iceland Basin is expected to be inadequate to support complete summer macronutrient drawdown. However, overall iron supply may only be marginally below that required for complete nitrate utilization to occur. Such a scenario explains the observed intensity of the spring bloom and the modest residual nitrate levels. Moreover, iron uptake and export during the bloom likely contributes to the reduced bioavailable iron levels which subsequently appear to limit the growth rates of at least some phytoplankton groups by early summer [Martin et al., 1993], consequently contributing to the development of a relatively weak HNLC condition. We (a)

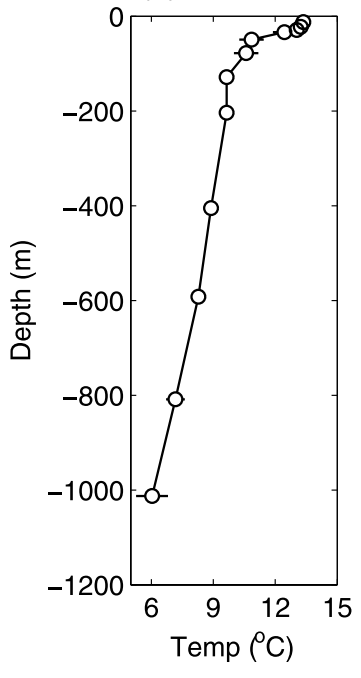

(b)

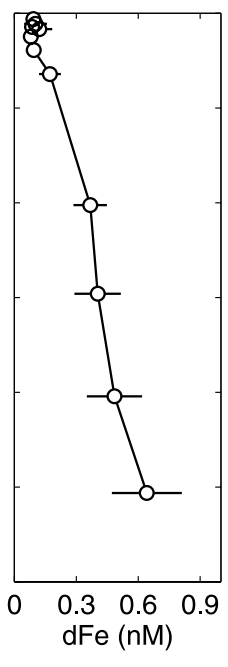

(c)

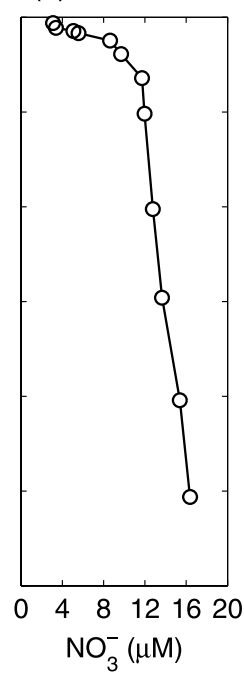

(d)

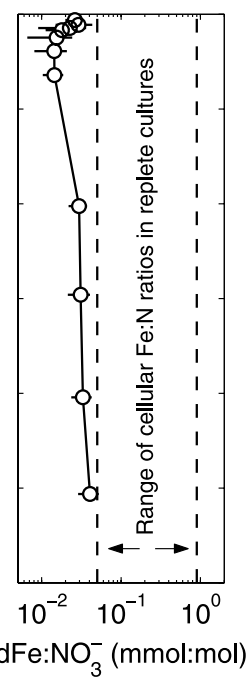

Figure 6. Average vertical profiles of (a) temperature, (b) dFe, (c) $\mathrm{NO}_{3}^{-}$, and (d) the $\mathrm{dFe}^{-} \mathrm{NO}_{3}^{-}$ratio compared to cellular Fe:N ratios within iron replete cultures [Ho et al., 2003; Sunda and Huntsman, 1995] which are comparable to in situ natural communities [Twining et al., 2004b]. Plotted values are mean values $( \pm 1 \mathrm{SE})$ from three to six profiles (depending on the depth) collected between 59.1 and $60^{\circ} \mathrm{N}$ and 18.7 and $20.6^{\circ} \mathrm{W}$. 
Table 3. The dFe Iron Profiles Collected Between 50.14 and $61.50^{\circ} \mathrm{N}$ and $19.12-20.61^{\circ} \mathrm{W}$ With Associated Temperature, Salinity, and Macronutrients $^{\mathrm{a}}$

\begin{tabular}{|c|c|c|c|c|c|c|c|c|}
\hline Station Details & Depth (m) & $\mathrm{dFe}(\mathrm{nM})$ & $\mathrm{SD}$ & Temperature $\left({ }^{\circ} \mathrm{C}\right)$ & Salinity & Nitrate $(\mu \mathrm{M})$ & Silicate $(\mu \mathrm{M})$ & Phosphate $(\mu \mathrm{M})$ \\
\hline \multirow[t]{12}{*}{ 16236, 8 Aug. $2007,59.14^{\circ} \mathrm{N}, 19.31^{\circ} \mathrm{W}$} & 7 & & & 13.381 & 35.223 & 2.4 & 0.2 & 0.3 \\
\hline & 12 & & & 13.216 & 35.2156 & 2.3 & 0.2 & 0.3 \\
\hline & 22 & $\mathrm{BD}$ & & 13.165 & 35.2159 & 2.3 & 0.2 & 0.2 \\
\hline & 29 & $\mathrm{BD}$ & & 13.165 & 35.2169 & 2.4 & 0.2 & 0.3 \\
\hline & 34 & $\mathrm{BD}$ & & 13.163 & 35.2161 & 2.6 & 0.3 & 0.3 \\
\hline & 50 & 0.059 & $( \pm 0.018)$ & 10.229 & 35.2127 & 8.7 & 2.2 & 0.8 \\
\hline & 78 & 0.041 & $( \pm 0.005)$ & 9.881 & 35.2316 & 9.7 & 3.2 & 0.8 \\
\hline & 128 & 0.142 & $( \pm 0.011)$ & 9.645 & 35.2487 & 9.7 & 3.2 & 0.8 \\
\hline & 204 & 0.274 & $( \pm 0.032)$ & 9.427 & 35.2659 & 10.8 & 5.6 & 0.9 \\
\hline & 406 & 0.527 & $( \pm 0.051)$ & 8.808 & 35.2364 & 11.4 & 6.8 & 1.0 \\
\hline & 609 & 0.765 & $( \pm 0.024)$ & 8.120 & 35.2051 & 11.9 & 7.8 & 1.1 \\
\hline & 810 & 0.789 & $( \pm 0.022)$ & 6.666 & 35.1131 & 13.8 & 11.9 & 1.3 \\
\hline \multirow[t]{10}{*}{ 16260, 12 Aug. $2007,59.19^{\circ} \mathrm{N}, 19.12^{\circ} \mathrm{W}$} & 5 & & & 13.408 & 35.2206 & 3.2 & 0.4 & 0.3 \\
\hline & 12 & 0.059 & $( \pm 0.000)$ & 13.409 & 35.2196 & 3.7 & 0.4 & 0.3 \\
\hline & 22 & 0.042 & $( \pm 0.000)$ & 12.903 & 35.2232 & 4.6 & 0.5 & 0.3 \\
\hline & 30 & 0.132 & $( \pm 0.001)$ & 12.396 & 35.2307 & 5.6 & 0.8 & 0.4 \\
\hline & 34 & 0.071 & $( \pm 0.000)$ & 10.774 & 35.2849 & 9.1 & 1.7 & 0.7 \\
\hline & 50 & 0.061 & $( \pm 0.000)$ & 10.101 & 35.2643 & 10.1 & 2.7 & 0.7 \\
\hline & 78 & 0.053 & $( \pm 0.000)$ & 9.967 & 35.2838 & 11.7 & 3.8 & 0.8 \\
\hline & 128 & 0.155 & $( \pm 0.001)$ & 9.684 & 35.2846 & 12.4 & 4.9 & 0.9 \\
\hline & 405 & 0.355 & $( \pm 0.002)$ & 9.056 & 35.2679 & 12.4 & 4.9 & 0.9 \\
\hline & 537 & 0.250 & $( \pm 0.001)$ & 8.783 & 35.2483 & 13.4 & 6.5 & 0.9 \\
\hline \multirow[t]{11}{*}{ 16282, 16 Aug. $2007,59.40^{\circ} \mathrm{N}, 20.61^{\circ} \mathrm{W}$} & 22 & $\mathrm{BD}$ & & 13.447 & 35.2311 & 3.2 & 0.4 & 0.2 \\
\hline & 29 & 0.015 & $( \pm 0.007)$ & 13.435 & 35.231 & 3.2 & 0.4 & 0.2 \\
\hline & 34 & 0.031 & $( \pm 0.077)$ & 13.406 & 35.2307 & 3.6 & 0.5 & 0.2 \\
\hline & 48 & $\mathrm{BD}$ & & 10.916 & 35.3362 & 10.7 & 2.6 & 0.7 \\
\hline & 77 & 0.033 & $( \pm 0.047)$ & 10.573 & 35.3413 & 11.2 & 3.6 & 0.7 \\
\hline & 127 & 0.028 & $( \pm 0.029)$ & 10.111 & 35.3124 & 12.0 & 4.7 & 0.8 \\
\hline & 204 & 0.040 & $( \pm 0.011)$ & 9.864 & 35.318 & 12.6 & 5.3 & 0.8 \\
\hline & 403 & 0.071 & $( \pm 0.019)$ & 9.265 & 35.2834 & 12.9 & 6.0 & 0.9 \\
\hline & 608 & 0.102 & $( \pm 0.019)$ & 8.550 & 35.2226 & 14.0 & 7.2 & 1.0 \\
\hline & 809 & 0.270 & $( \pm 0.058)$ & 7.277 & 35.1401 & 17.3 & 10.7 & 1.2 \\
\hline & 1013 & 0.350 & $( \pm 0.040)$ & 5.873 & 35.0741 & 16.9 & 12.2 & 1.3 \\
\hline \multirow[t]{12}{*}{ 16286, 19 Aug. $2007,59.24^{\circ} \mathrm{N}, 19.77^{\circ} \mathrm{W}$} & 7 & & & 12.873 & 35.2183 & 5.3 & 0.8 & 0.3 \\
\hline & 12 & 0.196 & $( \pm 0.016)$ & 12.873 & 35.2178 & 7.1 & 0.8 & 0.3 \\
\hline & 22 & 0.294 & $( \pm 0.040)$ & 12.791 & 35.221 & 5.7 & 0.8 & 0.3 \\
\hline & 29 & 0.090 & $( \pm 0.023)$ & 12.115 & 35.2299 & 6.9 & 1.3 & 0.4 \\
\hline & 34 & 0.408 & $( \pm 0.003)$ & 10.652 & 35.2448 & 9.4 & 2.5 & 0.6 \\
\hline & 49 & & & 9.636 & 35.2627 & 11.3 & 3.3 & 0.7 \\
\hline & 78 & 0.180 & $( \pm 0.016)$ & 9.285 & 35.2739 & 12.8 & 5.0 & 0.9 \\
\hline & 128 & 0.316 & $( \pm 0.025)$ & 9.063 & 35.2706 & 12.9 & 5.4 & 0.9 \\
\hline & 403 & 0.387 & $( \pm 0.008)$ & 8.941 & 35.284 & 12.6 & 5.5 & 0.9 \\
\hline & 598 & 0.417 & $( \pm 0.014)$ & 8.955 & 35.284 & 12.5 & 5.7 & 0.9 \\
\hline & 801 & 0.335 & $( \pm 0.018)$ & 8.876 & 35.266 & 12.8 & 5.9 & 0.9 \\
\hline & 1010 & 0.638 & $( \pm 0.051)$ & 7.450 & 35.1495 & 16.2 & 10.9 & 1.3 \\
\hline \multirow[t]{6}{*}{ IB16, 27 Aug. $2007,61.50^{\circ} \mathrm{N}, 20.00^{\circ} \mathrm{W}$} & 5 & & & 13.140 & 35.2403 & 3.0 & -0.0 & 0.2 \\
\hline & 35 & 0.044 & $( \pm 0.001)$ & 13.039 & 35.2387 & 3.8 & 0.1 & 0.2 \\
\hline & 78 & 0.132 & $( \pm 0.006)$ & 9.867 & 35.2303 & 19.5 & 3.6 & 0.7 \\
\hline & 616 & 0.406 & $( \pm 0.006)$ & 7.345 & 35.1607 & 31.4 & 10.7 & 1.1 \\
\hline & 809 & 0.497 & $( \pm 0.018)$ & 5.76 & 35.0631 & 31.4 & 10.8 & 1.1 \\
\hline & 1014 & 0.442 & $( \pm 0.005)$ & 4.537 & 34.9654 & 30.5 & 10.7 & 1.0 \\
\hline
\end{tabular}

${ }^{\mathrm{a}} \mathrm{BD}$, below detection limit.

thus suggest that the high-latitude North Atlantic only differs from the more severe HNLC high-latitude systems of the sub-Arctic Pacific and the Southern Ocean in the sense that higher iron and lower macronutrient inputs markedly increase bloom intensity and reduce the magnitude of the postbloom residual macronutrient pool, which is at least partially maintained by iron limitation.

\subsection{Wider Implications}

[44] The existence of a residual macronutrient pool within certain regions of the high-latitude North Atlantic represents an inefficiency in the biological soft tissue pump [Sarmiento and Toggweiler, 1984]. Persistence of such residual macro- nutrients within deep water formation regions raises preformed nutrient concentrations within North Atlantic Deep Water (NADW) and hence reduces the biological component of oceanic carbon storage [Marinov et al., 2008a, 2008b] Consequently, depending on the spatial and temporal extent of the residual macronutrient pool, it is possible that the existence of postbloom HNLC conditions in the high-latitude North Atlantic contributes significantly to ocean-atmosphere $\mathrm{CO}_{2}$ partitioning [Marinov et al., 2008a, 2008b]. Modeling studies have suggested that complete macronutrient depletion in this region could potentially reduce atmospheric $\mathrm{pCO}_{2}$ by $\sim 10 \mathrm{ppm}$ [Marinov et al., 2008b; Sarmiento and Orr, 1991]. 
However, we note that postbloom HNLC conditions may only contribute a fraction of this total, because of light limitation during late autumn.

\section{Conclusions}

[45] The results of the current study suggest that iron limitation of the postbloom phytoplankton community in the Iceland Basin is a factor contributing to the observed residual macronutrient pool. Mesoscale iron addition experiments have unequivocally shown that iron supply limits production in $>1 / 3$ of the global ocean where surface macronutrient concentrations are perennially high [Boyd et al., 2007]. Our study suggests that the high-latitude North Atlantic should be considered as an additional region where biogeochemical cycling may be sensitive to changes in iron inputs, for example, because of altered dust deposition patterns [Jickells et al., 2005].

[46] Acknowledgments. This work was supported by a Ph.D. studentship grant to M.C.N. by the National Oceanography Centre, Southampton, and by the Natural Environment Research Council through a standard grant (NE/E006833/1) to E.P.A., C.M.M. and R.S., a postdoctoral fellowship to C.M.M. (NE/C518114/2) and the Oceans2025 program of the National Oceanography Centre, Southampton, as well as a Faroese Ministry of Interior and Law research grant to M.C.N. The authors wish to thank the SeaWiFS program for the satellite data, the officers, crew, and entire scientific compliment aboard the R.R.S. Discovery during cruises D321a and D321b. We are particularly grateful to John Allen and Toby Sherwin as principal scientists, Mark Stinchcombe and Tim Brand for analyzing the macronutrient samples, Mike Lucas and Sandy Thomalla for chlorophyl analysis, and Alex Poulton for performing taxonomic identification and enumeration

\section{References}

Banse, K. (1982), Cell volumes, maximal growth-rates of unicellular algae and ciliates, and the role of ciliates in the marine pelagial, Limnol. Oceanogr., 27(6), 1059-1071.

Banse, K. (2002), Steemann Nielsen and the zooplankton, Hydrobiologia, 480(1-3), 15-28, doi:10.1023/A:1021220714899.

Behrenfeld, M. J., K. Worthington, R. M. Sherrell, F. P. Chavez, P. Strutton, M. McPhaden, and D. M. Shea (2006), Controls on tropical Pacific Ocean productivity revealed through nutrient stress diagnostics, Nature, 442(7106), 1025-1028, doi:10.1038/nature05083.

Bibby, T. S., M. Y. Gorbunov, K. W. Wyman, and P. G. Falkowski (2008), Photosynthetic community responses to upwelling in mesoscale eddies in the subtropical North Atlantic and Pacific oceans, Deep Sea Res. Part II, 55(10-13), 1310-1320, doi:10.1016/j.dsr2.2008.01.014.

Blain, S., U. Guieu, H. Claustre, K. Leblanc, T. Moutin, B. Queguiner, J. Ras, and G. Sarthou (2004), Availability of iron and major nutrients for phytoplankton in the northeast Atlantic Ocean, Limnol. Oceanogr. 49(6), 2095-2104.

Bowie, A. R., M. T. Maldonado, R. D. Frew, P. L. Croot, E. P. Achterberg, R. F. C. Mantoura, P. J. Worsfold, C. S. Law, and P. W. Boyd (2001), The fate of added iron during a mesoscale fertilisation experiment in the Southern Ocean, Deep Sea Res. Part II, 48(11-12), 2703-2743, doi:10.1016/S0967-0645(01)00015-7.

Bowie, A. R., E. P. Achterberg, P. L. Croot, H. J. W. de Baar, P. Laan, J. W. Moffett, S. Ussher, and P. J. Worsfold (2006), A communitywide intercomparison exercise for the determination of dissolved iron in seawater, Mar. Chem., 98(1), 81-99, doi:10.1016/j.marchem.2005.07.002.

Boyd, P. W., et al. (2000), A mesoscale phytoplankton bloom in the pola Southern Ocean stimulated by iron fertilization, Nature, 407(6805), 695702, doi:10.1038/35037500.

Boyd, P. W., A. C. Crossley, G. R. DiTullio, F. B. Griffiths, D. A. Hutchins, B. Queguiner, P. N. Sedwick, and T. W. Trull (2001), Control of phytoplankton growth by iron supply and irradiance in the subantarctic Southern Ocean: Experimental results from the SAZ Project, J. Geophys. Res., 106(C12), 31,573-31,583, doi:10.1029/2000JC000348.

Boyd, P. W., et al. (2007), Mesoscale iron enrichment experiments $1993-$ 2005: Synthesis and future directions, Science, 315(5812), 612-617, doi: $10.1126 /$ science. 1131669
Crawford, D. W., et al. (2003), Influence of zinc and iron enrichments on phytoplankton growth in the northeastern subarctic Pacific, Limnol. Oceanogr., 48(4), 1583-1600.

Cullen, J. J. (1991), Hypotheses to Explain high-nutrient conditions in the open sea, Limnol. Oceanogr., 36(8), 1578-1599.

Cullen, J. J., and R. F. Davis (2003), The blank can make a big difference in oceanographic measurements, Limnol. Oceanogr. Bull., 12, 29-35.

de Baar, H. J. W., et al. (2005), Synthesis of iron fertilization experiments: From the Iron Age in the Age of Enlightenment, J. Geophys. Res., 110, C09S16, doi:10.1029/2004JC002601.

de Jong, J. T. M., J. den Das, U. Bathmann, M. H. C. Stoll, G. Kattner, R. F. Nolting, and H. J. W. de Baar (1998), Dissolved iron at subnanomolar levels in the Southern Ocean as determined by ship-board analysis, Anal. Chim. Acta, 377, 113-124, doi:10.1016/S0003-2670(98)00427-9.

Ducklow, H. W., and R. P. Harris (1993), Introduction to the JGOFS North Atlantic bloom experiment, Deep Sea Res. Part II, 40(1-2), 1-8, doi:10.1016/0967-0645(93)90003-6.

Dugdale, R. C., and F. P. Wilkerson (1998), Silicate regulation of new production in the equatorial Pacific upwelling, Nature, 391(6664), 270-273, doi:10.1038/34630.

Frost, B. W. (1991), The role of grazing in nutrient-rich areas of the open sea, Limnol. Oceanogr., 36(8), 1616-1630.

Geider, R. J., and J. La Roche (1994), The role of Iron in phytoplankton photosynthesis, and the potential for iron-limitation of primary productivity in the sea, Photosynth. Res., 39(3), 275-301, doi:10.1007/ BF00014588.

Gervais, F., U. Riebesell, and M. Y. Gorbunov (2002), Changes in primary productivity and chlorophyll $\mathrm{a}$ in response to iron fertilization in the Southern Polar Frontal Zone, Limnol. Oceanogr., 47(5), 1324-1335.

Greene, R. M., R. J. Geider, Z. Kolber, and P. G. Falkowski (1992), Ironinduced changes in light harvesting and photochemical energy-conversion processes in eukaryotic marine algae, Plant Physiol., 100(2), 565 575, doi:10.1104/pp.100.2.565

Greene, R. M., Z. S. Kolber, D. G. Swift, N. W. Tindale, and P. G. Falkowski (1994), Physiological limitation of phytoplankton photosynthesis in the eastern equatorial Pacific determined from variability in the quantum yield of fluorescence, Limnol. Oceanogr., 39(5), $1061-1074$

Hamm, C. E., R. Merkel, O. Springer, P. Jurkojc, C. Maier, K. Prechtel, and V. Smetacek (2003), Architecture and material properties of diatom shells provide effective mechanical protection, Nature, 421(6925), 841-843, doi:10.1038/nature01416.

Henson, S. A., R. Sanders, C. Holeton, and J. T. Allen (2006), Timing of nutrient depletion, diatom dominance and a lower-boundary estimate of export production for Irminger Basin, North Atlantic, Mar. Ecol. Prog. Ser, 313, 73-84, doi:10.3354/meps313073.

Ho, T. Y., A. Quigg, Z. V. Finkel, A. J. Milligan, K. Wyman, P. G. Falkowski, and F. M. M. Morel (2003), The elemental composition of some marine phytoplankton, J. Phycol., 39(6), 1145-1159, doi:10.1111/j.0022-3646.2003.03-090.x

Honjo, S., and S. J. Manganini (1993), Annual Biogenic particle fluxes to the interior of the North Atlantic Ocean; studied at $34^{\circ} \mathrm{N} 21^{\circ} \mathrm{W}$ and $48^{\circ} \mathrm{N}$ $21^{\circ} \mathrm{W}$, Deep Sea Res. Part II, 40(1-2), 587-607, doi:10.1016/09670645(93)90034-K.

Hutchins, D. A., and K. W. Bruland (1998), Iron-limited diatom growth and $\mathrm{Si}: \mathrm{N}$ uptake ratios in a coastal upwelling regime, Nature, 393(6685), $561-564$, doi: $10.1038 / 31203$.

Jickells, T. D., et al. (2005), Global iron connections between desert dust, ocean biogeochemistry, and climate, Science, 308(5718), 67-71, doi:10.1126/science.1105959.

Johnson, K., E. Boyle, K. Bruland, C. I. Measures, J. W. Moffett, and S. Team (2005), SAFe: Sampling and analysis of iron in the ocean, Geophys. Res. Abstr., 7, abstract 05813.

Johnson, K. S., R. M. Gordon, and K. H. Coale (1997), What controls dissolved iron concentrations in the world ocean?, Mar. Chem., 57(34), 137-161, doi:10.1016/S0304-4203(97)00043-1.

Knox, F., and M. B. McElroy (1984), Changes in atmospheric $\mathrm{CO}_{2}$ : Influence of the marine biota at high latitude, J. Geophys. Res., 89(D3), 4629-4637, doi:10.1029/JD089iD03p04629.

Kolber, Z. S., R. T. Barber, K. H. Coale, S. E. Fitzwater, R. M. Greene, K. S. Johnson, S. Lindley, and P. G. Falkowski (1994), Iron limitation of phytoplankton photosynthesis in the equatorial Pacific Ocean, Nature, 371(6493), 145-149, doi:10.1038/371145a0.

Kolber, Z., O. Prásil, and P. G. Falkowski (1998), Measurements of variable chlorophyll fluorescence using fast repetition rate techniques: Defining methodology and experimental protocols, Biochim. Biophys. Acta, 1367 , 88-106, doi:10.1016/S0005-2728(98)00135-2. 
Landing, W. M., C. Haraldsson, and N. Paxeus (1986), Vinyl polymer agglomerate based transition metal cation-chelating ion-exchange resin containing the 8-hydroxyquinoline functional group, Anal. Chem., 58(14), 3031-3035, doi:10.1021/ac00127a029.

Marinov, I., M. Follows, A. Gnanadesikan, J. L. Sarmiento, and R. D. Slater (2008a), How does ocean biology affect atmospheric $p \mathrm{CO}_{2}$ ? Theory and models, J. Geophys. Res., 113(C7), C07032, doi:10.1029/2007JC004598.

Marinov, I., A. Gnanadesikan, J. L. Sarmiento, J. R. Toggweiler, M. Follows, and B. K. Mignone (2008b), Impact of oceanic circulation on biologica carbon storage in the ocean and atmospheric $\mathrm{pCO}_{2}$, Global Biogeochem Cycles, 22(3), GB3007, doi:10.1029/2007GB002958.

Martin, J. H., and S. E. Fitzwater (1988), Iron deficiency limits phytoplankton growth in the north-east Pacific subartic, Nature, 331, 341-343, doi:10.1038/331341a0.

Martin, J. H., S. E. Fitzwater, R. M. Gordon, C. N. Hunter, and S. J. Tanner (1993), Iron, primary production and carbon nitrogen flux studies during the JGOFS North Atlantic bloom experiment, Deep Sea Res. Part II, 40(1-2), 115-134, doi:10.1016/0967-0645(93)90009-C.

Martin, J. H., et al. (1994), Testing the iron hypothesis in ecosystems of the equatorial Pacific Ocean, Nature, 371(6493), 123-129, doi:10.1038/ $371123 \mathrm{a} 0$.

Measures, C. I., W. M. Landing, M. T. Brown, and C. S. Buck (2008), High-resolution $\mathrm{Al}$ and $\mathrm{Fe}$ data from the Atlantic Ocean CLIVAR-CO Repeat Hydrography A16N transect: Extensive linkages between atmospheric dust and upper ocean geochemistry, Global Biogeochem. Cycles, 22, GB1005, doi:10.1029/2007GB003042.

Moore, C. M., M. I. Lucas, R. Sanders, and R. Davidson (2005), Basinscale variability of phytoplankton bio-optical characteristics in relation to bloom state and community structure in the northeast Atlantic, Deep Sea Res. Part I, 52(3), 401-419, doi:10.1016/j.dsr.2004.09.003.

Moore, C. M., M. M. Mills, A. Milne, R. Langlois, E. P. Achterberg, K. Lochte, R. J. Geider, and J. La Roche (2006), Iron limits primary productivity during spring bloom development in the central North Atlantic, Global Change Biol., 12(4), 626-634, doi:10.1111/j.13652486.2006.01122.x.

Moore, C. M., S. Seeyave, A. E. Hickman, J. T. Allen, M. I. Lucas, H. Planquette, R. T. Pollard, and A. J. Poulton (2007), Iron-light interactions during the CROZet natural iron bloom and EXport experiment (CROZEX) I: Phytoplankton growth and photophysiology, Deep Sea Res. Part II, 54(18-20), 2045-2065, doi:10.1016/ j.dsr2.2007.06.011.

Morel, F. M. M., J. G. Reuter, and N. M. Price (1991), Iron nutrition of pytoplankton and its possible importance in the ecology of ocean regions with high nutrients and low biomass, Oceanography, 4, 56-61.

Obata, H., H. Karatani, and E. Nakayama (1993), Automated determination of iron in seawater by chelating resin concentration and chemiluminescence detection, Anal. Chem., 65, 1524-1528, doi:10.1021/ ac00059a007.

Obata, H., H. Karatani, M. Matsui, and E. Nakayama (1997), Fundamental studies for chemical speciation of iron in seawater with an improved analytical method, Mar. Chem., 56(1-2), 97-106, doi:10.1016/S03044203(96)00082-5.

Poulton, A. J., C. M. Moore, S. Seeyave, M. I. Lucas, S. Fielding, and P. Ward (2007), Phytoplankton community composition around the Crozet Plateau, with emphasis on diatoms and Phaeocystis, Deep Sea Res. Part II, 54(18-20), 2085-2105, doi:10.1016/j.dsr2.2007.06.005.

Price, N. M., B. A. Ahner, and F. M. M. Morel (1994), The equatoria Pacific Ocean-Grazer-controlled phytoplankton populations in an ironlimited ecosystem, Limnol. Oceanogr., 39(3), 520-534.

Raven, J. A. (1990), Predictions of Mn and Fe use efficiencies of phototrophic growth as a function of light availability for growth and of $\mathrm{C}$ assimilation pathway, New Phytol., 116(1), 1-18, doi:10.1111/j.14698137.1990.tb00505.x.

Sanders, R., and T. Jickells (2000), Total organic nutrients in Drake Passage, Deep Sea Res. Part I, 47(6), 997-1014, doi:10.1016/S09670637(99)00079-5

Sanders, R., L. Brown, S. Henson, and M. Lucas (2005), New production in the Irminger Basin during 2002, J. Mar. Syst., 55(3-4), 291-310, doi:10.1016/j.jmarsys.2004.09.002

Sarmiento, J. L., and J. C. Orr (1991), 3-dimensional simulations of the impact of Southern Ocean nutrient depletion on atmospheric $\mathrm{CO}_{2}$ and ocean chemistry, Limnol. Oceanogr., 36(8), 1928-1950.

Sarmiento, J. L., and J. R. Toggweiler (1984), A new model for the role of the oceans in determining atmospheric $p \mathrm{CO}_{2}$, Nature, 308(5960), 621624, doi:10.1038/308621a0.

Siegel, D. A., S. C. Doney, and J. A. Yoder (2002), The North Atlantic spring phytoplankton bloom and Sverdrup's critical depth hypothesis, Science, 296(5568), 730-733, doi:10.1126/science.1069174.

Siegenthaler, U., and T. Wenk (1984), Rapid atmospheric $\mathrm{CO}_{2}$ variations and ocean circulation, Nature, 308(5960), 624-626, doi:10.1038 $308624 \mathrm{a} 0$.

Suggett, D. J., C. M. Moore, A. E. Hickman, and R. J. Geider (2009), Interpretation of fast repetition rate (FRR) fluorescence: Signatures of phytoplankton community structure versus physiological state, Mar. Ecol. Prog. Ser., 376, 1-19, doi:10.3354/meps07830.

Sunda, W. G., and S. A. Huntsman (1995), Iron uptake and growth limitation in oceanic and coastal phytoplankton, Mar. Chem., 50(1-4), 189206, doi:10.1016/0304-4203(95)00035-P.

Sunda, W. G., and S. A. Huntsman (1997), Interrelated influence of iron, light and cell size on marine phytoplankton growth, Nature, 390(6658), 389-392, doi: $10.1038 / 37093$

Sverdrup, H. U. (1953), On conditions for the vernal blooming of phytoplankton, J. Cons., 18, 287-295.

Twining, B. S., S. B. Baines, and N. S. Fisher (2004a), Element stoichiometries of individual plankton cells collected during the Southern Ocean Iron Experiment (SOFeX), Limnol. Oceanogr., 49(6), 2115-2128.

Twining, B. S., S. B. Baines, N. S. Fisher, and M. R. Landry (2004b), Cellular iron contents of plankton during the Southern Ocean Iron Experiment (SOFeX), Deep Sea Res. Part I, 51(12), 1827-1850, doi:10.1016/j.dsr.2004.08.007.

Vassiliev, I. R., O. Prasil, K. D. Wyman, Z. Kolber, A. K. Hanson, J. E. Prentice, and P. G. Falkowski (1994), Inhibition of PS II photochemistry by PAR and UV radiation in natural phytoplankton communities, Photosynth. Res., 42(1), 51-64, doi:10.1007/BF00019058.

Walsh, J. J. (1976), Herbivory as a factor in patterns of nutrient utilization in sea, Limnol. Oceanogr., 21(1), 1-13.

Welschmeyer, N. A. (1994), Fluorometric analysis of chlorophyll-a in the presence of chlorophyll-b and pheopigments, Limnol. Oceanogr., 39(8), $1985-1992$.

Zondervan, I. (2007), The effects of light, macronutrients, trace metals and $\mathrm{CO}_{2}$ on the production of calcium carbonate and organic carbon in coccolithophores-A review, Deep Sea Res. Part II, 54(5-7), 521-537, doi:10.1016/j.dsr2.2006.12.004

E. P. Achterberg, D. J. Hinz, C. M. Moore, M. C. Nielsdóttir, and R. Sanders, Ocean Biogeochemistry and Ecosystems Research Group, National Oceanography Centre, School of Ocean and Earth Science, University of Southampton, European Way, Southampton SO14 3ZH, UK. (mon@noc. soton.ac.uk) 